tenure of chairs at Bristol (1933) and at Glasgow (1937-46).

'Trueman's researches, though closely related, fall into three main categories largely resulting from and conditioned by the experience gained from his detailed and original morphological, ontogenetic and phylogenetic studies on ammonites. Accounts of the evolution of several families of ammonites wore followed by similar studies on gastropods and the lamellibranch Gryphaea. Characteristically, Trueman recognized the implications of his palæontological discoveries in terms of their practical application towards a fuller: understanding of Jurassic chronology and of their usefulness in zonal subdivision of these rocks in the field. 'Thus concomitant work described the palæontology of the Lias rocks from Lincolnshire and South Nottinghamshire to Somerset and Glamorganshire.

There followed that part of his work concerned with appreciation of the fundamental conceptions involving genera and species, of populations and of variability, and of the impact of such considerations upon taxonomy. His contributions to the more philosophical aspects of palæontology ranged among other topics, from lineage and orthogenesis, to a reconsideration of the species concept in palæontology, and eulminated during his revision of the Coal Measures Non-marine Lamellibranchs (1927) in the application of biometric techniques to a study of variation in fossil communities and to the use of statistical investigations in detailed correlation. Work by Trueman, and others who have since extended his conceptions, has led to radical changes in outlook and added considerably towards evaluation of funda. mental processes in evolution.

Trueman's later work dealt with the palæontology and with varied aspects of the stratigraphy of the British Coal Measures. Tho purely palæontological studies of the Coal Measures non-marine lamellibranchs from South Wales soon enabled him to indicato their practical applications in the identification of coal seams, and resulted in a zonal subdivision of the South Wales Coal Measures in 1927, leading to a suggested correlation of the British coalfields (1933). The detailed application of this zonal scheme to every major British coalfield, and the utilization of the accruing evidence in exploration within coalfields, or during boring for extensions or for new fields, by Trueman, independent workers and by officers of the Geological Survey bear witness to its efficacy. Indeed, this subdivision has formed the accepted method of presentation in all important papers and memoirs since its inception, and has contributed largely to a rationalization of Coal Measures stratigraphy, as summarized by Trueman in his presidential addresses to the Geological Society of London. 'The publication of a Palæontographical Society Memoir on the Coal Measures non-marine lamellibranchs in collaboration with Dr. J. Weir marks still further an important permanent record of widespread researches which constitute a major contribution to geological science.

Acknowledgment of his work by election to the Royal Society followed in 1942; the Geological Society of London awarded him the Bigsby Medal (1939) and the Wollaston Medal (1955).

Sir Arthur was enorgetically concerned for the welfare of geological science at all levels and published. a number of books, in general illustrated by himself, and which were of interest to the layman, the school pupil or the student. However, his interests and knowledge were considerably more widespread and embraced many aspects of the educational field and of its organization and its contacts with science and industry. This knowledge made him a wolcome member of many committees, such as the Elliot Commission on educational problems in West Africa, the Advisory Council on Scientific Policy, and as chairman of the Geological Survey Board.

Those who were fortunate to como under his influence either as students or staff regarded him with respect and affection, for his kindness, integrity and sympathetic understanding made him a friond in whom one felt complete confidence. His charm of manner and keen sense of humour, combined with a remarkably quick grasp of problems and wise judgment in their solution, convinced one of his very personal interest in every member of his department, student and staff alike. No student ever sought Trueman's help or advice in vain. He was always ready to discuss work and ideas and contrived to make all feel their ideas were interesting and their results important. As a leader he was a deep source of inspiration and encouragement, and possessed that inestimable gift of putting a person at ease. His enthusiasm and zeal were combined with a vital and ceaseless energy which he imparted to others; his lucidity of mind and exposition made him a great lecturer and superb teacher, in the lecture theatre, and above all in the field.

This remarkable combination of wide university experience, achievement, leadership, organizing ability and high moral integrity led to his appointment as deputy chairman of the University Grants Committee in 1946, and its chairman in 1948. In this office, at a time of critical importance in the developments of the British university system, Trueman contributed much by his knowledge, influence and wise counsel. Unfortunately, his period of office was limited, for he fell ill late in 1952 and soon afterwards resigned.

During the last years of his life Trueman struggled with great and uncomplaining fortitude against increasing physical disability, his mind alert and active, his sense of humour unimpaired; and during this time, with indomitable spirit he wrote parts of, and edited contributions for, his last book, "The Coalfields of Great Britain", a project which had been in his mind for many years.

Sir Arthur is survived by Lady 'Trueman and their son, E. R. Trueman. Lady Trueman's companionship, help, understanding and encouragement contributed greatly towards his many achievements, and her unselfish devotion during the later years enabled him to face his disability with great courage. LESLIE R. MOORE

\section{Prof. Duncan Leitch}

THE tragically premature death of Prof. Duncan Leitch at the age of fifty-two, a week after that of his friend and colleague, Sir Arthur Trueman, came as a shock even to those friends who knew of his grave illness.

Leitch was a graduate of the University of Glasgow and served there as assistant and lecturer in geology until, in 1947, he succeeded Prof. 'T. Neville George in the chair of geology at the University College of Swansea.

Leitch's main scientific work was concerned with the palæontology and stratigraphy of the Coal Measures. He collaborated with me in zoning the 
Scottish Coal Measures by the successive assemblages of non-marine bivalves that are fossilized in these rocks. Afterwards he used the zones in elucidation of an obscure section of Coal Measures in Arran, and gave accounts of variation in several groups of these fossils, notably of Lower Carboniferous and Namurian Naiadites which are peculiar to Scotland and are doubtless forerunners of the numerous and more widely distributed guide fossils of this genus in the Coal Measures. His most notable work on this line, however, was the admirably detailed biometric description of variation in a community of Anthra. conaia [Anthracomya] from the Central Coalfield of Scotland, prepared with the help of Dr. R. A. Robb, which made an important contribution to taxonomic method in the study of these highly variable animals, and explained various anomalies in their vertical distribution within the Coal Measures.

At Swansea Leitch had established a research team to continue the study of these principles and their application to field-problems, especially in the structurally difficult measures of Pembrokeshire; but his premature death has inevitably deferred the fulfilment of this work.

For several years he was secretary of Section C (Geology) of the British Association.

Leitch was a kindly, friendly man who loved company, an attribute that was reflected in his happy relations with students in laboratory and field. He leaves a widow and young son.

J. WeIR

\section{Sir Richard Redmayne, K.C.B.}

Sir Richard Redmayne, who died on December 27, was born at Low Fell, County Durham, in 1865. $\mathrm{He}$ was the son of John Marriner Redmayne, of Low Fell-a lover of the fine arts and no mean painter in water colours and a devout Christian : attributes fully inherited by his son. His grandfather, Giles Redmayne, built and endowed Brathay Church in Westmorland and was complimented on its structure by the poet Wordsworth.

Sir Richard served his apprenticeship at the Hetton Collieries under William Armstrong, a famous mining engineer who had been apprenticed to the celebrated John Buddle, the 'father of the Coal Trade' and intimate friend of George Stephenson of locomotive fame. At one period in his training he rose at 2.30 a.m., and walked a mile and a half to the mine, which he descended at 3.30 and came out at 10.30. In the afternoon he attended the office to write reports and do other administrative work. $\mathrm{He}$ also studied at the Durham College of Science-now King's College, Newcastle upon Tyne. He becarne an under-manager and in 1891 left England to undertake mining operations in South Africa. In 1893 he was appointed manager of a group of collieries at Seaton Delaval. On that occasion the Rev. C. H. Boutflower-afterwards Bishop of Tokyo and later of Southamptonwrote as follows :

"Turn on the buzzer, blow the horns, bang all the tubs together !

Let every Gall'way neigh response, each driver crack the leather!

Oh happy day-let Seaton say-and happiest news to tell of all

Dick is become our Manager of Mines at Seaton Delaval."

In 1902 Sir Richard was appointed professor of mining at the University of Birmingham and, writing as one of his" first students, I can say that all those who studied under him will honour his memory for his great kindness and the hospitality of his home by the then Mrs. Redmayne, who was the ideal hostess. Sir Richard retired from the chair at Birmingham to become the first H.M. Chief Inspector of Mines at the Home Office, and I was very fortunate in serving him as private secretary for two years. His appointment caused a little jealousy among a fow of the then senior inspectors, but the justification of his selection was soon evident. Very early he had to investigate and report upon some of the largest colliery explosions which have occurred in Britain. At that time the late Sir William Garforth had conducted large-scale experiments at Altofts Colliery, where there had been a serious explosion, demonstrating the explosive nature of coal dust and the possibility of neutralizing its nature by the application of stone dust. Sir Richard decided immediately to strengthen the regulations relating to safety and drafted a Bill which became the Coal Mines Act, 1911. This Act, based on practical and scientific knowledge, foresight and common sense, is, at the moment, still in operation. This fact indicates the soundness of its structure. In my opinion this Act was Sir Richard's magnum opus. Its enforcement resulted in diminishing rapidly the loss of life from such disasters.

Another potential source of danger existed-the danger of open sparking and shock from the application of electricity in mines; and a committee of experts was appointed to consider the inadequacy of the Electrical Special Rules of 1905. The committee consisted of Sir Richard as chairman, Mr. C. H. Merz and Mr. Robert Nelson, who had been appointed the first H.M. Electrical Inspector of Mines. New rules were established and Mr. Nelson enforced them with tact to the great benefit of the industry.

After the firedamp explosions at the Jamage Pit in North Staffordshire and at Cadeby Colliery in Yorkshire (where the Divisional Inspector and eighty. seven others were killed), which were caused as the result of spontaneous combustion, the Home Secretary set up a departmental committee with Sir Richard as chairman to inquire into the circum. stances in which spontaneous combustion of cosl occurs in mines, its causes and the means of preventing it, and a Blue Book was issued. A code of rules was afterwards drawn up on the organization for rescue and aid in the case of accidents in mines. Now there are numerous rescue stations and trained men in all the coalfields of Britain.

It is perhaps true to say that no man in his profession has filled so many posts and performed such various duties. Sir Richard was a member of three Royal Commissions. He was chairman of the Board for Mining Examinations for many years and was external examiner in mining for the Universities of London, Birmingham, Wales and New Zealand, and examiner for the Camborne School of Mines, the Board of Education and the City and Guilds of London. Sir Richard was held in such high esteem by H.M. Civil servents that he was elected for thirtythree years in succession as president of the Institution of Professional Civil Servants. He was also a past-president of the Institutions of Civil Engineers and of Mining and Metallurgy.

This appreciation might appear to be overloaded if a complete list of the offices Sir Richard held were given. He had been. a director in a number of colliery and other companies and for many years acted as a 